\title{
Theorising Chance
}

Citation for published version (APA):

Gladkova, N., \& Mazzucato, V. (2017). Theorising Chance: Capturing the Role of Ad Hoc Social Interactions in Migrants' Trajectories. Population Space and Place, 23(2), e1988. [1988].

https://doi.org/10.1002/psp.1988

Document status and date:

Published: 01/03/2017

DOI:

10.1002/psp.1988

Document Version:

Publisher's PDF, also known as Version of record

\section{Document license:}

Taverne

\section{Please check the document version of this publication:}

- A submitted manuscript is the version of the article upon submission and before peer-review. There can be important differences between the submitted version and the official published version of record.

People interested in the research are advised to contact the author for the final version of the publication, or visit the DOI to the publisher's website.

- The final author version and the galley proof are versions of the publication after peer review.

- The final published version features the final layout of the paper including the volume, issue and page numbers.

Link to publication

\footnotetext{
General rights rights.

- You may freely distribute the URL identifying the publication in the public portal. please follow below link for the End User Agreement:

www.umlib.nl/taverne-license

Take down policy

If you believe that this document breaches copyright please contact us at:

repository@maastrichtuniversity.nl

providing details and we will investigate your claim.
}

Copyright and moral rights for the publications made accessible in the public portal are retained by the authors and/or other copyright owners and it is a condition of accessing publications that users recognise and abide by the legal requirements associated with these

- Users may download and print one copy of any publication from the public portal for the purpose of private study or research.

- You may not further distribute the material or use it for any profit-making activity or commercial gain

If the publication is distributed under the terms of Article $25 \mathrm{fa}$ of the Dutch Copyright Act, indicated by the "Taverne" license above, 


\title{
Theorising Chance: Capturing the Role of Ad Hoc Social Interactions in Migrants' Trajectories
}

\author{
Nataliia Gladkova* and Valentina Mazzucato \\ Faculty of Arts and Social Sciences, Maastricht University, Maastricht, The Netherlands
}

\begin{abstract}
When collecting migrants' life stories, researchers often report on the role of chance encounters in influencing the way migration trajectories have taken shape or how migrants have managed their lives in a new country. Aside from reporting on such encounters, however, there have been no explicit efforts to theorise chance or to make it central to in-depth analysis in migration studies. This paper aims to theorise the role of chance encounters in migrants' trajectories by drawing on insights from the psychology literature of chance encounters and life paths. Our analysis of the role of chance encounters, structured by the interplay between environmental and personal factors, suggests that how people deal with chance is an influential factor in the ways people migrate from the Global South to the Global North and manage their lives in transit. The paper makes use of evidence collected among 46 African migrants in Ukraine during 7 months of field research in 2011-2012 and reflects on the methodological implications in studying chance. Copyright (C) 2015 John Wiley \& Sons, Ltd.
\end{abstract}

Accepted 25 August 2015

Keywords: chance; transit migration; trajectories; Africa

\section{INTRODUCTION}

I came to Ukraine to further my education. My broker met me at the airport in Kiev and took

\footnotetext{
*Correspondence to: Nataliia Gladkova, Faculty of Arts and Social Studies, Maastricht University, Maastricht, The Netherlands. E-mail: n.gladkova@maastrichtuniversity.nl
}

my passport and all the money I had. We had to take an overnight train to go to the university campus. Next morning I found myself abandoned by the broker at the train station of a city unknown to me. I did not speak the language! I did not know what to do! I was lucky to see an African man. After I explained to him my situation he said: 'Man, you are nobody in this country without documents'. He directed me to an accommodation center for asylum seekers and refugees. There I met more people who advised me to plot a story and apply for asylum to temporarily legalise my stay (Charly, ${ }^{1}$ 25, Cameroonian).

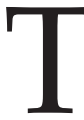
he story of a young Cameroonian migrant in Ukraine illustrates that even if the purpose of the journey and the destination are known, at any moment in time contingencies, usually socially mediated, can emerge and bring changes into an envisaged trajectory (Pascualde-Sans, 2004). Unlike expatriates whose relocation and placement are usually facilitated by human resource specialists, migrants moving from the Global South to the Global North seem to be more exposed to risks and opportunities arising from chance.

Although migration researchers acknowledge the importance of chance encounters in ethnographic studies, there have been no explicit efforts to theorise chance or to make it central to in-depth analysis. Therefore, there is no theoretical framework for studying chance in the migration process. In part, the lack of interest in studying chance can be attributed to the aim of social scientific inquiry to search for structures, regularities, and lasting relationships. Chance events are ephemeral by their nature and often seen as exceptional and insignificant when aiming to make powerful generalisable statements (Manis \& Meltzer, 1994). Yet psychologists 
have recognised the role of chance in influencing life paths (Bandura, 1998; Krantz, 1998; Shanahan \& Porfeli, 2006) and educational and occupational careers (Bright et al., 2005; Chen, 2005). However, the role of chance in migration experiences has not been analysed by these studies.

The central claim of this paper is that chance encounters play a significant role in influencing migration trajectories and that it is therefore necessary to understand how people manage chance encounters. Trajectories are open-ended processes, which are shaped by migrants' decisions and actions in response to emotional, practical, and structural challenges that they experience from the moment they start to plan their trip (Grillo, 2007). Such a perspective conceptualises migration as a constantly evolving process, emphasising changes in migrants' geographical location, legal, occupational, or marital statuses.

The paper builds on data collected among subSaharan Africans in Ukraine as part of a study on how sub-Saharan migrants use their transnational social networks to develop survival and mobility strategies. African migration to Europe has become for many migrants a long-lasting, fragmented, and highly risky endeavour (Collyer, 2007; Schapendonk, 2011). It is characterised by a high degree of unpredictability and often includes stays in 'waiting hubs' or 'transit zones', which may last from a few days to a lifetime (Collyer et al., 2012; Hess, 2012). We conducted our study prior to the 2014 outbreak of the armed conflict, when Ukraine was such a hub. Complex and opaque visa application procedures encourage migrants to actively search for alternative ways to overcome the impossibility of travelling (Grillo \& Mazzucato, 2008). Some aspiring migrants after assessing their chances to obtain a Schengen visa strategically decide to opt for a 'more affordable' and less time-consuming choice on the 'menu' and migrate to a country located on the European periphery with the hope to further move to the European Union. Others act rapidly and agree to travel to a country, which they know little or nothing about, if they are presented with an opportunity to travel abroad. Thus, a country like Ukraine, even though it lacks colonial and historical ties with the African continent, has become a country of destination and passage for migrants coming from sub-Saharan Africa (Düvell, 2006). Enumeration of sub-Saharan migrants in Ukraine is problematic as official statistics are missing. Based on the estimates of experts working in the field of migration and asylum, the community of sub-Saharan African in Ukraine has been estimated at 15,000 individuals.

The paper starts by identifying a lacuna in migration studies. Secondly, the role of chance encounters in the migration process is theorised by drawing on prior theoretical developments in psychology. Two bodies of literature, migration and psychology of chance and life paths, that have to date remained separate, are brought to bare on each other. Thirdly, the paper reflects on the methodological tools used for capturing chance encounters in migrants' life stories. Finally, the paper investigates how an analytical framework set out by psychologists can be applied to the study of chance in migration trajectories by analysing in-depth interviews collected among 46 African migrants in Ukraine. In so doing, we identify some important modifications to the framework that need to be made when studying migrants' lives. By focusing on the role of chance encounters in migrants' trajectories, we aim to contribute to a more systematic analysis of chance among migration scholars and stimulate further research.

\section{THEORISING CHANCE IN THE MIGRATION PROCESS}

\section{Present But Not Theorised: Chance Encounters in Migration Studies}

When collecting migrants' life stories, migration researchers often report the role of chance encounters in influencing the way a migration trajectory took shape and how migrants managed their lives in a new country (Papadopoulou, 2004; Yükseker \& Brewer 2011; Collyer, 2007; Schapendonk, 2011，2012; Suter, 2012). While not focusing on chance encounters, existing ethnographic studies of migration trajectories mention weak, fragile, spontaneous, and instrumental ties emerging during the journey.

A first attempt to distinguish a new set of transnational social ties that could sometimes determine the success or failure of the migration process was made by Dahinden (2005). In her study on Albanian migration networks from former Yugoslavia, Dahinden shows that 14 out of 15 interviewees said that during their journey, it was mainly people they did not know who had

Popul. Space Place 2017; 23: e1988 DOI: $10.1002 / \mathrm{psp}$ 
given them instrumental and informational support. These encounters represent dynamic and fugitive elements within the networks, as they appear only once during the migration process. The author argues that for the investigation of how migrants decide to migrate, survive in a new environment, and reintegrate on return, fleeting and dynamic network elements are as important as strong ties.

Based on the research among trans-Saharan transit migrants in Morocco, Collyer distinguishes two types of ties in migrants' social networks: spontaneous and absent. Absent ties are strong, affective relationships with people back home. Spontaneous ties are those that migrants create and maintain with individuals they encounter during their journey. In the absence of family and close friends, chance encounters at different stages of African migrants' journeys to Morocco frequently provide the means for continued migration (Collyer, 2007: 679-682).

In a study on social networks of Nigerian migrants in Istanbul, Suter (2012: 209) emphasises the role of new encounters upon migrants' arrival to a new destination. The author claims that in transit contexts and in the absence of strong ties, weak, fragile, and utility-based ties prevail. Schapendonk also calls for more attention to the role of transient social ties, which are important to migrants during their journey. He notices that while analysing social connections during the act of moving, one might come across 'a more dynamic version of networks that contrasts the grid-like understandings of strong and weak ties' (Schapendonk, 2012: 36). In his dissertation, Schapendonk points out that some of the new encounters, which help migrants to get ahead, would fit into a conventional understanding of a social network approach as they turn into strong or weak ties over time, while others would not and thus cannot be automatically considered to be a part of social network (Schapendonk, 2011: 138).

Some studies shift analytical attention towards broader factors in society determining chance occurrences. For example, in the investigation of the reasons underlying asylum seekers' choice of country of refuge, Havinga and Böcker (1999: 57) found that many asylum seekers arrived in the country of asylum accidentally. This can be explained by non-random circumstances or opportunities that asylum seekers encounter like border checks, immigration policies, access to visas, and travel connections, which put migrants into dependence on fortuity.

Aside from these ethnographic studies, largescale quantitative migration studies tend to exclude chance from analysis because of the analytical methods used. Probabilistic methods based on the power of large numbers exclude chance occurrences as these are, by their very nature, anomalous events (Ray \& van Oudenaarden, 2008). In such a way, these methods eliminate the role of chance in individual migration stories.

Thus, for the most part, migration studies, using both quantitative and qualitative approaches, have neither conceptualised nor provided a framework for the systematic analysis of the role of chance in migrants' lives. It is therefore necessary to look beyond migration studies to develop a theoretical framework for the analysis of chance encounters in the migration process.

\section{Towards an Analytical Framework for Studying Chance in Migration Trajectories}

The concept of chance has been mostly discussed among philosophers, sociologists, and psychologists who tried to provide alternatives to a deterministic approach to social science. Most scholars agree that chance events can take either interpersonal forms, with a human agency involvement (e.g. a meeting), or impersonal forms, caused by non-human agency (e.g. winning a lottery, sudden illness, and a car crash). Psychologist Albert Bandura (1982) was the first among his colleagues to focus on fortuitous human encounters and to offer a theoretical model for the analysis of chance encounters in life paths.

Bandura conceptualises chance as 'an unintended meeting of persons unfamiliar with each other' (Bandura, 1982: 748). He postulates that two sets of separate but interactive constructs should be taken into consideration as we try to understand how chance affects the life course: personal determinants and social milieus. On the personal side, chance meetings are most likely to affect life courses if they get converted into a lasting relationship. Interpersonal attraction, as well as personal characteristics such as people's attributes, belief systems, interests, and competences influence whether a chance encounter will turn into a strong tie or not. On the social side, the impact of chance encounters depends on the 'holding and shaping power of the milieus into 
which people are fortuitously inaugurated' (Bandura, 2001: 12). Social circles with their beliefs, value systems and prescribed behaviour patterns, and the kind of people who populate them make some chance encounters more probable and leave a stronger impact on people's lives than others (Bandura, 1982).

In the types of migration trajectories described previously, chance events are mainly interpersonal; thus, our analysis focuses on this type of chance manifestation. In order to develop a theoretical framework for the analysis of the role of chance encounters in the migration process, we draw on Bandura's conceptual scheme. It allows us to systematise the analysis and to bring it beyond the description of cases as has been carried out in the ethnographic literature. While adapting Bandura's theoretical model to the study of migration trajectories, it is important to state that there are some points of difference that derive from the migration context. We define chance encounter as a migrant's transitory social interaction with a previously unknown person that is perceived by him or her as unintentional and can be viewed as a risk or an opportunity in the future.

Firstly, we deliberately introduced 'perceived unintentionality' in the proposed definition of a chance encounter for migration studies, because a meeting perceived by a migrant as unplanned may not be purely random. Bandura (1982: 748) used the term 'degree of fortuitiveness' to emphasise the fact that people sometimes intentionally seek certain types of activities. Shanahan and Porfeli pointed out that many chance events 'are not specifically intended, although they represent occurrences that could reasonably be anticipated because of a broader intention' (Shanahan \& Porfeli, 2006: 106). Moreover, 'by selecting activities, settings, organisational involvements, and relationships, people actively affect the likelihood of specific future events' (ibid.: 101).

Secondly, based on the anecdotal evidence in the migration studies presented earlier and our own observations, Bandura's claim that chance encounters play a significant role in a person's life course if they get converted into a lasting relationship does not seem to be a necessary condition. Our research suggests that the transformation of chance meetings into a lasting bond is not a determining factor for whether a chance encounter will have a lasting effect on migrants' life paths. Each social interaction is an opportunity for the exchange of information or support, although not every social interaction results in a durable connection. In fact, many chance encounters are composed of a single interaction that cannot be classified as a weak or strong tie. Some chance encounters may develop over time into a lasting relationship in case of marriages or friendships produced by an accidental meeting. Yet these latter are taken into consideration by studies focusing on migrants' social networks and families. Rather, it is our contention that we need more research attention precisely on those transitory social interactions that do not become lasting ties but have a significant impact on a migrant's trajectory and life course.

Thirdly, interpersonal attraction is often not a prerequisite for a chance encounter to happen and to develop into a lasting relationship. Bandura notes that 'chance meetings are more likely to affect life courses when individuals come to like people they meet or gain other satisfactions from them' (1982: 750). While we acknowledge that interpersonal attraction seals chance encounters into lasting bonds, it is 'perceived' similarity that increases the propensity of social interactions. In social networks studies, this phenomenon is explained by homophily. McPherson, Smith-Lovin, and Cook define homophily as 'the principle that a contact between similar people occurs at a higher rate than among dissimilar people' (2001: 416).

According to Mayhew et al. (1995), people sharing similar socio-demographic characteristics may be expected to share a similar knowledge base and experience. Chelpi-den Hamer and Mazzucato (2010) observe that many newly arrived West Africans in the Netherlands received support from other sub-Saharan Africans. Previous studies showed that bounded solidarity emerges among members of a particular group who find themselves affected by common events in a particular time and place (Portes \& Sensenbrenner, 1993). It is thus to be expected that an African migrant in a new environment would intuitively try to approach people of colour.

\section{METHODOLOGY}

One of the reasons that chance has not received the attention it deserves is that it is difficult to study empirically. Here, we set out the methodology that allowed us to detect the role of chance in

Popul. Space Place 2017; 23: e1988 DOI: $10.1002 / \mathrm{psp}$ 
migrants' trajectories, without claiming that it is the only way to do so. Field research lasted 7 months in 2011-2012 and was carried out in the three largest migrant hubs of Ukraine: Kiev, Kharkov, and Odessa. The sample consisted of 46 sub-Saharan African male migrants reflecting the largest sub-Saharan migrant groups in Ukraine: Nigerian $(N=18)$, Cameroonian $(N=19)$, and Ghanaian $(N=9)$ and the fact that most migrants from these countries of origin are men.

We aimed for a diverse sample in order to capture the variety of experiences of African migrants in Ukraine and the role that chance plays in their lives. Having no base statistics on this migrant population, we used a combination of sampling techniques: snowballing, contacts through gate keepers, targeted site selection (both physical sites and virtual sites such as http://badoo. com), and random encounters.

The study used both qualitative and quantitative methods of data collection. First, a social network analysis (SNA) survey was conducted, which collected data on migrants' profiles and members of migrants' personal social networks using a multiple name generator tool (Campbell \& Lee, 1991). Subsequently, migrants were interviewed focusing on their life stories relating to their migration trajectories as well as on the relationships with people they mentioned. We adopted a biographical approach advocated by some migration scholars (Halfacree \& Boyle, 1993; Findlay \& Li, 1997). Respondents could structure their life stories the way they wanted. Lives of migrants are full of disruptions, delays, contradictions, and incomplete goals, and it is often reflected in the way they recount their stories. We tried to ensure the most important themes for our research as pre-migration experience and expectations, decision-making, events, and experiences en route; current circumstances and plans for future were covered by asking open-ended questions. It was important for the researcher to have an open stand and be flexible in order to pick up on chance and ask further about it.

An additional interview was conducted in which migrants were asked to reflect on the changes in their personal networks at the different stages of their life course. For this purpose, participatory visualisations of personal social networks obtained during the quantitative stage of data collection were used. Visual images of migrants' networks were produced with the help of NetDraw and then recreated on an iPad tablet with the help of the OmniGraffle App. This interactive technique produced many references to ad hoc but meaningful interactions, which had not been captured during the social network survey. Their absence in the SNA survey and their emergence during the visualisation exercise helped to reveal the significance of these encounters and to focus our questioning on these. After this, and if migrants directly mentioned chance encounters, they were asked to reflect explicitly about the effects of chance encounters on their lives.

Participatory observations of daily routines also contributed to the elicitation of chance encounters. For example, when a respondent, Samuel, was talking to another respondent, Godwin, we noticed that this relationship was not reported by either of the two respondents. During the second round of in-depth interviews, Samuel, a Cameroonian asylum seeker, said that Godwin was the first person of colour whom he randomly met at the market:

Being a good Cameroonian brother, Godwin helped me to get a small job and was paying for my accommodation for the few first months (Samuel, 29, Cameroonian).

While explaining why Samuel did not include Godwin in his personal social network, Samuel says:

He is not important for me. It was then. Now I don't need him (Samuel, 29, Cameroonian).

When asked about this relationship and whether it was an oversight to not include it in the network study, Samuel insisted on not including the person who provided vital support during the initial stage of his stay in Ukraine in the personal social network study due to what he perceived of as Godwin's minor role in his life. The more affluent Godwin did not include Samuel in his personal network because he classified his assistance as an act of charity. Triangulating sources of information helped unveil certain types of ad hoc relationships and enabled further questioning, which revealed the ways that ad hoc relationships are perceived.

Interview sessions lasted from $30 \mathrm{~min}$ to $2 \mathrm{~h}$. Each respondent was interviewed from two to six times. Analysis of data generated from in-depth 
interviews and participatory observations was conducted in a few steps. Firstly, each interview transcript was reviewed twice, for content understanding and for identification of useful comments and impressions noted as observations. Multiple references to 'chance', 'luck', and 'fortune' were identified at this stage of analysis. Secondly, based on the data and the conceptual literature on psychology of chance encounters and life paths, we developed descriptive and interpretative categories and further basic themes. Finally, we identified predominant themes that served as a basis for the construction of a conceptual model for studying chance encounters in the migration process.

\section{ENCOUNTERING AND MANAGING CHANCE}

There are different ways in which people react to chance encounters: some individuals dismiss the influence of chance on their choices and experiences, others surrender to chance as though victims to it, while others embrace it in trying to capitalise on the fortuitous nature of life. Psychology studies argue that personal characteristics and the social environment in which a person is embedded are both important in determining the influence of fortuitous meetings on people's lives. Bandura's analytical model, modified to include the empirical insights from our data, is shown in Figure 1.

In the analysis that follows, we will first look at migrants' social environments and then construct analytical categories of migrants based on their personal characteristics exhibited in responding to chance encounters. We acknowledge that there are migrants who are less exposed to chance encounters. Usually, these people are 'better off' in terms of financial resources and documentation compared with other migrants in whose life trajectories chance encounters more easily hold sway. In our sample, migrants who could dismiss the role of chance in their life stories were mainly students. They could rely on financial support from personal social networks and were used to overcome contingencies with the power of money or connections. In the analysis, we will focus on the part of our sample of migrants who faced relatively similar exposure to chance due to their dire situation and explain why they reacted differently.

\section{Social Environment}

\section{Uncertainty and insecurity}

Migration is informed by, generates, and improves uncertainty (Williams \& Baláž, 2012: 167). Once the border is crossed but a final destination is not yet reached, migrants may find themselves to be more vulnerable and unprotected than ever

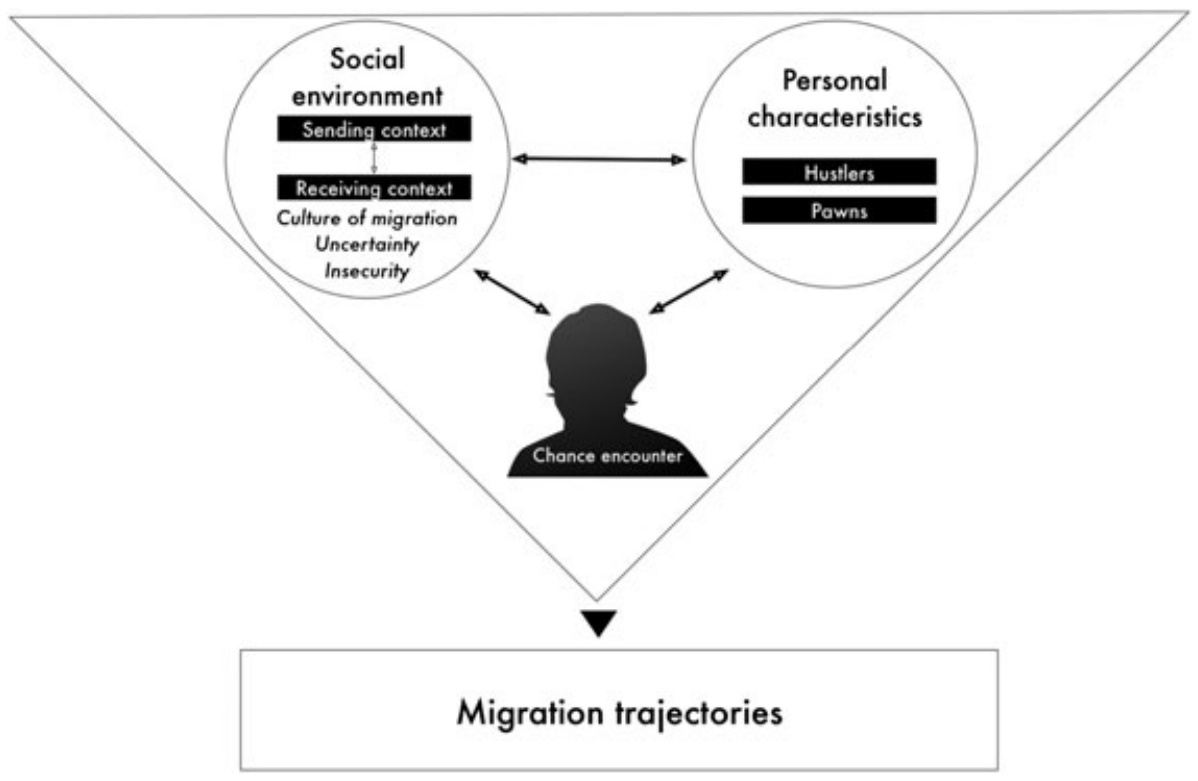

Figure 1. A modified Bandura's conceptual scheme for studying chance encounters in the migration process. 
before. The environment of uncertainty and insecurity, where transit migrants often find themselves, is a result of three main factors: 'illegality' of their status, 'temporality' of their situation, and restraining role of smugglers and traffickers (İçduygu \& Sert, 2014).

Uncertainty and insecurity of transit migrants' daily lives are a product of structural factors such as migration controls, lack of employment opportunities, poor living standards, and fast-changing legislation and policies, which are socially mediated. As a consequence, many young Africans turn out to be unprepared for a hostile social environment in Eastern Europe, where they can easily be exploited by fellow migrants or smuggles, who control migrants' crossings, time of departure and even destinations, or harassed by the local population and law enforcement authorities.

To surmount contingences and stress encountered in everyday life in Africa, people usually draw on informal support systems based on wellestablished social networks. In Ukraine, African migrants seldom have prior strong ties with locals or with other foreigners. Thus, upon arrival, they have to rely on weak ties and newly created ad hoc connections, many of which are produced by chance. This observation is supported by Bandura's claim that when social ties are weak or lacking, 'vulnerability' to fortuitous influences increases (Bandura, 1982: 754). The probability to meet new people accidentally and to be affected by these chance encounters is especially high during the first few months of stay in the host country and decreases over time when migrants acquire basic language and cultural competences:

When I arrived I made new friends by chance. You know, black people always greet each other on the street. I was strolling outside my hostel and met many people around. I had to rely on people I hardly knew. Not that I really rely on them, but when you are in a strange land, you look for someone who could help. Now, when I speak Russian and know the city, I can manage by myself (Thierry, 24, Cameroonian).

\section{Culture of migration}

In many parts of West Africa where poverty, unemployment, and corruption have become a 'routinised part of everyday life, more and more people are dreaming of migrating, actually moving, or facilitating the travel of family and friends abroad. Thierry who originates from Bamenda, Anglophone province in Cameroon, with a long history of internal and external migration, explains his aspiration to move abroad referring to his childhood memories:

When I was child I had many friends from abroad. When I was schooling in Bamenda my father had many friends who were coming from abroad to greet the family. I had that idea to fly out since... When I got my school diploma, the only thing that was on my mind was to fly out. Everyone at home tried their best to satisfy my dream (Thierry, 24, Cameroonian).

These ideas, practices, aspirations, and images of migration create a 'culture of migration' (Kandel \& Massey, 2002; Ali, 2007). In West Africa, such a culture favours international migration and contributes to the probability of a spontaneous meeting of unacquainted persons who are linked to each other through the shared symbolic environment and its acceptance as a valid source of information. Constant information flows among migrants, aspiring migrants, and migration brokers have vastly increased the power of the symbolic environment on people's ways of thinking and patterns of behaviour (Alpes, 2012). Therefore, an increasing number of migrants actively search for alternative ways to overcome the impossibility of travelling imposed by complex and unclear migration regulations in Europe with the help of prayer, money, connections, or chance. Alpes (2012: 103) notes that in Anglophone Cameroon, travelling is viewed as overcoming 'closure', and hence, migrants look for 'openings' in order to move abroad. If they find or hear about a new 'opening', they have to 'rush'; otherwise, it can close, and nobody knows when a new opportunity will arise. This, at times, involves taking advantage of chance encounters. It can be a total stranger met in a bar or on the street who might sow the seeds in the mind of a potential migrant and change his behaviour. The story of Costal illustrates how this culture of migration led him to his encounter with Eric and to see it as an 'opening' rather than as a source of unreliable, which in its turn influenced Costal's initial migration project:

A friend of mine asked me to go to the Embassy of Tunisia in Yaoundé to inquire for 
information. He wanted to study medicine in Tunisia. On the street, next to the Embassy, I met a guy called Eric who told me that we should look at Ukraine. According to him, Ukraine was a much better country for studies and living. Myself, I was planning to go to Italy, because I speak Italian. I knew that it was very difficult to receive an Italian visa. Eric has managed to convince me to change my initial plans. My friend, who wanted to go to Tunisia, is also in Ukraine studying aviation. I thought: 'why not?' I did not know anybody there. The only thing I knew was that people speak Russian or Ukrainian and it is very cold there. Was it a normal decision to travel to an unknown country without any prior knowledge? Now I would say 'no'. At that time I saw an opportunity and I had to react (Costal, 25, Cameroonian).

If Costal and Eric were not connected through a culture of migration that regards information, even from strangers, as an 'opening', this chance encounter would have had little likelihood of occurring and of having an impact on Costal's plans. Instead, it branched Costal into new life trajectory.

\section{Personal Characteristics}

Having argued that the social environment exposes people to differing degrees to chance encounters, there is also a difference in how people will react to such encounters. We therefore turn to the question of what distinguishes these different types of individuals based on how they react to chance. Bandura (1982) explains the variation in responses to chance encounters by personal susceptibilities to social factors. In the following analysis, we will focus on the personal proclivities that along with socio-economic characteristics are most discussed in the literature on the role of chance in people's life paths: chance awareness (Chen, 2005; Shanahan \& Porfeli, 2006), openness to experience (Wiseman, 2003; Chen, 2005; Ho, 2011), and personal values and attitudes (Bandura, 1982, 1998).

We distinguish two analytical categories of migrants based on personal characteristics relating to chance: hustlers and pawns. The former deliberately include chance into their survival and mobility strategies and try to capitalise on the unpredictable nature of life; the latter exercise little or no control over chance effects.

Equally vulnerable to accidental encounters due to limited financial means and lack of support, hustlers and pawns show dissimilar reactions when they are confronted with chance in the same context of uncertainty and insecurity. We base the term hustlers on a word that is commonly used by migrants themselves to indicate people who know how to use chance to their benefit. Openness to experience, willingness to compromise or adjust one's values and beliefs, and an opportunistic attitude characterise the way West African migrants, who consider themselves to be hustlers, define this notion. While in Western contexts, hustling is associated with criminal activities (Venkatesh, 2009); in West African contexts, hustling has acquired a slightly different meaning, especially with respect to migration. One of our respondents provided his definition of hustling:

Initially, 'hustling' meant to do something illegal, like being involved in prostitution or selling drugs. Today to hustle means to do any kind of job to raise money whether legally or illegally (Bolaji, 29, Nigerian).

Alpes defines hustling as 'working hard and accepting any possible type of work, or means of support' (Alpes, 2014: 263-264). Ho (2011), in her study of migration trajectories of 'highly skilled' Singaporean transmigrants in London, identifies a category of migrants whom she calls 'accidental navigators', who prolong their stay in the UK through chance strategies. Similar to these highly skilled Singaporeans in London, some African migrants in Ukraine have an open and proactive attitude that allows for a multitude of options and possibilities that these migrants derive from random and unexpected occurrences.

Pawn is a term used in the psychology literature to describe people who are moved into a situation not by their own choosing. They feel that they are pushed around, as if they are puppets in someone's hands and can exercise very little control over the developments in their lives (DeCharms, 1968) (Table 1).

\section{Chance awareness}

In career counselling, increasing client's awareness of the role and function of chance is a way 
Table 1. Analytical categories - chance coping behaviour.

\begin{tabular}{|c|c|c|}
\hline Personal characteristics & Hustlers & Pawns \\
\hline $\begin{array}{l}\text { Chance awareness and } \\
\text { openness }\end{array}$ & $\begin{array}{l}\text { Intentionally incorporate an element of } \\
\text { chance in their migration strategies }\end{array}$ & Passively submit to chance encounters \\
\hline Openness to experience & $\begin{array}{l}\text { Skilled at creating and noticing chance } \\
\text { encounters }\end{array}$ & $\begin{array}{l}\text { Forced to use chance under dire } \\
\text { circumstances }\end{array}$ \\
\hline Personal values and attitudes & $\begin{array}{l}\text { Flexible, adjustable set of personal values } \\
\text { perceive chance as an opportunity }\end{array}$ & $\begin{array}{l}\text { Relatively stable set of values perceive } \\
\text { chance as a risk }\end{array}$ \\
\hline
\end{tabular}

to help clients minimise the negative effects of chance and optimally use chance to influence one's career pathway (Chen, 2005: 258). Some migrants not only understand this recipe of coping with chance but intuitively incorporate chance awareness in their migration strategies:

Chance does not come itself. Somebody has to initiate a room for it. Chance is a wonderful thing! If you make good use of it, it affects life (Henry, 41, Nigerian migrant).

Henry's opportunistic attitude to chance illustrates how hustlers perceive unexpected occurrences. Hustlers' projections of the future often have references to unanticipated circumstances that can alter their course of life or migration project, as Muntala explains:

I am still hoping for the better future anywhere. It does not really matter where... How I can change the destiny? It might depend on the situation and what might happen in the near future. The future comes and I work with it (Muntala, 28, Ghanaian).

Pawns, on the other hand, do not think about chance encounters before they are confronted with them and often perceive chance meetings as an act of fate rather than a result from deliberate action. The story of Peter is an illustration of this category of migrants. Peter, a 23-year-old Cameroonian young man, had to flee his country of origin for fear of persecution. Peter's departure from Cameroon was organised in a hurry by his close friend and under the threat of arrest. Peter did not take either his mobile phone or any documents with him. Peter expected to arrive in Equatorial Guinea or Gabon, but after spending 3 months in the cargo department of a banana boat, Peter found himself in a port in Ukraine:
I left the boat and tried to approach people in the port, but nobody wanted to talk to a dirty black man or could not speak English. The only person who responded to my cry for help was an Arab who said that there was a big community of Africans in Kharkov. He bought me a ticket to Kharkov and put me on a bus. The same day I arrived to Kharkov. On the street I met an African who brought me to Barabashevo outdoor market (that day it was working at night). There I met some Cameroonians and one of them hosted me in his house for the next six months (Peter, 23, Cameroonian Kharkov).

While Peter made use of chance encounters in his first arrival to Ukraine because he had no place to go, he did so only when it was absolutely necessary. In fact, a year after arriving in Ukraine, when we met and interviewed Peter, his personal social network consisted of eight persons, while only two of them were local contacts. He spent most of his spare time in his apartment. The little contact he had with others meant that he did not receive information on how to improve his situation. This became apparent when we found that Peter was not aware that he could apply for asylum.

\section{Openness to experience}

One of the hallmarks of a hustler is openness to new encounters and experience. Proactive, entrepreneurial, and inquisitive individuals able to take quick decisions under uncertainty will be more equipped in identifying opportunities and capitalising on meetings by chance. Bandura (2001) notes that chance encounters do not occur autonomously and people can make them happen by pursuing an active life. In the literature on career counselling, openness is considered to be the first and foremost important requirement in coping with unforeseen events (Chen, 2005). 
Titus exemplifies this openness when describing how he builds his personal social network through the example of how he met one of the researchers:

You need to work towards chance. Not everybody knows how to meet people. You are gaining from meeting people. You come across me through a friend. See, I am open for new experiences. Look at the way you met me (Titus, 39 , Nigerian).

The migration process of Africans coming to Europe is characterised by a complex and rapidly changing context due to changes in laws and policies at national and European levels, new information that migrants may access, as well as a highly variable way in which laws are enacted by border enforcers on the ground. Migrants who are open are thus better equipped to deal with such a variable environment. Hustlers' prior experience with chance - whether successful or failed - deriving from their ability to embrace the opportunities that come their way makes them skilful chance managers. They recognise situations in which it is appropriate to embrace chance and others in which it is best to walk away:

Chance is something, which is very important if you are in a position to recognise and accept it. This recognition gives you power. Not every chance is acceptable and positive (Henry, 41, Nigerian).

Openness to experience does not come natural to pawns who usually perceive chance encounters in terms of risk. If pawns make use of a chance encounter, it is usually imposed by external forces. Apata describes his acceptance of chance encounters only as a matter of desperation:

Life...Sometimes you don't know how it ends. I met someone from Afghanistan in a mosque. I explained to him my situation and he offered me a place where I could lay my head. I saw him once. Maybe he would take my eyes off as I fall asleep or help me as a Muslim brother. I accepted his offer, because I needed it. If everything is okay with me, we would just meet in a bar, have a short conversation: 'Good-bye good-bye...' Normally, we would meet 2-3 times to develop a relationship. If a woman would park her car right in front of me, I would not care how she looks, I need a place to sleep and to eat (Apata, 28, Nigerian).

The story of Samuel, an asylum seeker from Cameroon, is another example of how pawns take a passive stance towards chance when they find themselves in a dire situation:

I am telling you when I arrived I was so confused, because I never knew where I am. I just had 50 dollars on me. I don't really know what happened. Somebody just told me to come here [from the port in Odessa where he arrived by boat to Kharkov]. This guy, he was black, he helped me to exchange dollars into Ukrainian money. He did everything. I was just standing there... I don't know his name and I did not ask for his telephone number. I don't really like to be in touch with anybody. That is my life, I just want to be left alone... I normally don't talk to strangers (Samuel, 29, Cameroonian).

\section{Personal values and attitudes}

I met a guy at the border. He wanted me to bring 5-10 foreigners who would like to go to Europe. If they are arrested, the officer will get a promotion. I am not that kind of a guy. I need money, but not anyhow. If I bring people from Africa I can raise thousands of dollars, but I will never do that. It is better for me to risk my own life. I don't want to make money out of someone's sufferings. If I rob a bank, it is my own responsibility. I'm a kind of person like that. That's how my parents brought me. I know do's and don't's (Apata, 28, Nigerian).

Apata confirms Bandura's argument that the influence of chance encounters is likely to be greater when people are prone to adjust their norms and personal standards (Bandura, 1982: 751). Confronted with chance encounters, migrants have to decide for themselves whether a chance meeting is an opportunity or a risk. In this process, they are usually guided by personal values and attitudes. Pawns like Apata try to stick to their sets of values and beliefs. On the one hand, these internal guides may help Apata to avoid additional risks related to becoming a trafficker and serve as the only safeguard mechanisms that enable migrants like Apata to resist 
possible negative effects of chance encounters. On the other hand, being governed by his value standards, Apata loses a chance to broaden his personal network and improve his financial situation. Bandura notes that 'in the absence of internal guides and normative consensus fortuitous influences more easily hold sway' (ibid.). Hustlers seem to be more willing to compromise or adjust their personal standards and beliefs if they are confronted with an encounter that may change their migration trajectory:

I found an American church in Odessa on the Internet. I am the only Black guy there. Back home I was going to a different church. There is one God. Maybe they could help me to move to America (Titus, 39, Nigerian).

Pawns often perceive failures to realise their migration projects as personal catastrophes, while hustlers are rarely discouraged by failures and disconnections in their migration projects and view deportations as a part of the game:

If I am sent back to Nigeria, I will stay there just to raise money and to travel to somewhere else. Like I did when I was deported from Malaysia (Kenneth, 28, Nigerian).

An involuntary return is usually treated by hustlers as an opportunity to raise their social status in the country of origin by demonstrating that he or she has become a 'worldly person' able to overcome the impossibility of travelling (Alpes, 2014).

\section{DISCUSSION AND CONCLUSIONS}

Risks and opportunities arising from chance encounters have always characterised any trajectory whether it is a voyage or a life course. Psychologists emphasise that individuals are most vulnerable to effects of chance during life transitions (Cabral \& Salomone, 1990). Migration can be seen as a transition in a person's life. Migration of African migrants to and through Eastern Europe is a good observatory for how chance is dealt with differentially and how it can alter trajectories because chance encounters are many. Without paying attention to such encounters that fall out of usual theoretical frameworks for studying the migration process, our understanding of migrants' lives and their trajectories will be incomplete.

In order to study the role of chance encounters in migrants' trajectories, we applied Bandura's (1982) conceptual scheme for studying chance encounters in life paths to migration. We adapted Bandura's framework to reflect the migration context. Most social psychological studies focus on unintended meetings, which turn into lasting relationships such as meeting one's prospective marriage partner. We highlight that many of the meaningful encounters in migrants' lives are ephemeral as they do not have to be long lasting to have a significant effect on migrants' lives. Even if chance encounters in the migration context may not be as random as they are perceived by migrants because of homophily and bounded solidary, they are nonetheless encounters that tend to be ignored or unduly theorised in migration research that focuses on more stable relationships. Furthermore, by discussing the importance of the social environment, we emphasised the uncertain and insecure contexts in both the countries of origin and destination and the culture of migration, which create an environment more prone to chance encounters and allowing them to have an effect on one's life.

The framework that we propose poses particular methodological challenges because chance encounters may be difficult to detect, precisely because of their ephemeral quality in the migration context. Manis and Meltzer (1994: 54) argue that quantitative methods of inquiry are less likely to uncover social fortuities than narrative, ethnographic, and other qualitative case study techniques. Yet, we have found that applying more than one method, in our case, one based on social network data collection and another based on qualitative interviews, allowed us to triangulate, which led to a more detailed probing of chance encounters than if only one method were used. In some cases, qualitative biographical accounts may be full of references to unplanned and unexpected meetings, which produced a chain of life-changing events. This may be strongly influenced by the system of beliefs informing a respondent's account, as well as by the dire situation in which migrants find themselves on the way to Europe. In Western societies where individual agency, control, and rationality are valued and emphasised, respondents may give less importance in their narratives to chance 
meetings (Shanahan \& Porfeli, 2006: 110). The life histories of African migrants that we collected were full of references to 'chance', which intertwine strong notions of free individual agency with ideas of fate and a predetermined destiny (Nieswand, 2010).

Combining respondent's qualitative accounts of their trajectories with the structured social network, questionnaire and interactive visualisations helped to identify ephemeral relationships and explore the meanings given to these relationships through in-depth probing precisely because they were missing in one method and present in another. The detailed conversations that ensued helped us to identify the concepts that respondents used to explain their management of chance encounters or lack thereof.

Our research indicates that a focus on chance helps to broaden our knowledge of factors that influence migration trajectories. By looking at personal characteristics of people whose life courses have been affected by chance, we came up with two categories of migrants that enabled us to better understand why certain people respond differently to chance encounters even if they find themselves in a similar situation. Hustlers and pawns who do not possess financial means and cannot rely on trustful sources of support seem to show different reactions in the similar social environment. Hustlers due to their chance awareness, openness to new experience, and adjustable set of values and personal standards tend to see chance as an opportunity, while pawns mostly perceive chance in terms of risk and hazard.

How the interplay of social milieus and these three types of chance management behaviours affects the actual shape that migration trajectories take is an area for further investigation. A longitudinal study on whether people's attitudes towards chance change and how this relates to changes in their socio-economic status or social environment would form a fruitful way to advance this area of research. In order to evaluate the impact of chance encounters in migrants' lives, new methodological tools are needed. SNA tools like name generators and name interpreters could be modified to elicit transitory but meaningful social interactions and contain questions on the way contacts were established. Surveys could be constructed in order to investigate how chance events are distributed in different stages of the migration process. Additionally, surveys could be instrumental for the understanding of the relationship between migrants' personal attributes and perceived chance events. Once captured by SNA tools or chance event surveys, the role of social encounters in migrants' life could be further explored with the help of qualitative techniques. While collecting qualitative data on chance encounters, researchers should be aware that people select events and assign meaning and direction to their narratives under the influence of their social environments, norms, and beliefs.

\section{NOTE}

(1) All personal names are pseudonyms.

\section{REFERENCES}

Ali S. 2007. 'Go West young man': the culture of migration among Muslims in Hyderabad, India. Journal of Ethnic and Migration Studies 33: 37-58.

Alpes MJ. 2012. Bushfalling at all cost: the economy of migratory knowledge in Anglophone Cameroon. African Diaspora 5(1): 90-115.

Alpes MJ. 2014. Imagining a future in 'bush': migration aspirations at times of crisis in Anglophone Cameroon. Identities: Global Studies in Culture and Power 21(3): 259-274.

Bandura A. 1982. The psychology of chance encounters and life paths. American Psychologist 37(7): 747-755.

Bandura A. 1998. Exploration of fortuitous determinants of life paths. Psychological Inquiry 9(2): 95-99.

Bandura A. 2001. Social cognitive theory: an agentic perspective. Annual Review of Psychology 52: 1-26.

Bright J, Pryor R, Wilkenfeld S, Earl J. 2005. The role of social context and serendipitous events in career decision making. International Journal for Educational and Vocational Guidance 5: 19-36.

Cabral AC, Salomone PR. 1990. Chance and careers: normative versus contextual development. Career Development Quarterly 39(1): 5-11.

Campbell KE, Lee BA. 1991. Name generators in surveys of personal networks. Social Networks 13(3): 203-221.

Chelpi-den Hamer M, Mazzucato V. 2010. The role of support networks in the initial stages of integration: the case of West African newcomers in the Netherlands. International Migration 48(2): 31-57.

Chen CP. 2005. Understanding career chance. International Journal for Educational and Vocational Guidance 5: 251-270.

Collyer M. 2007. In-between places: trans-Saharan transit migrants in Morocco and the fragmented journey to Europe. Antipode 39(4): 668-690.

Popul. Space Place 2017; 23: e1988 DOI: $10.1002 / p s p$ 
Collyer M, Düvell F, de Haas H. 2012. Critical approaches to transit migration. Population, Space and Place 18(4): 407-414.

Dahinden J. 2005. Contesting transnationalism? Lessons from the study of Albanian migration networks from former Yugoslavia. Global Networks 5(2): 191-208.

DeCharms R. 1968. Personal Causation. Academic Press: New York.

Düvell F. 2006. 'Ukraine - Europe's Mexico?'. Research Resources Report 1/3: Country Profile. COMPAS, University of Oxford.

Findlay AM, Li FLN. 1997. An auto-biographical approach to understanding migration: the case of Hong Kong emigrants. Area 29(1): 34-44.

Grillo R. 2007. Betwixt and between: trajectories and projects of transmigration. Journal of Ethnic and Migration Studies 33(2): 199-217.

Grillo R, Mazzucato V. 2008. Africa $<>$ Europe: a double engagement. Journal of Ethnic and Migration Studies 34(2): 175-198.

Halfacree K, Boyle P. 1993. The challenge facing migration research: the case for a biographical approach. Progress in Human Geography 17: 333-348.

Havinga T, Böcker A. 1999. Country of asylum by choice or by chance: asylum-seekers in Belgium, the Netherlands and the UK. Journal of Ethnic and Migration Studies 25(1): 43-61.

Hess S. 2012. De-naturalising transit migration. Theory and methods of an ethnographic regime analysis. Population, Space and Place 18: 428-440.

Ho ELE. 2011. Migration trajectories of 'highly skilled' middling transnationals: Singaporean transmigrants in London. Population, Space and Place 17(1): 116-129.

İçduygu A, Sert D. 2014. Migrants' uncertainties versus the state's insecurities transit migration in Turkey. In Transit Migration in Europe, Düvell F, Molodikova I, Collyer M (eds). Amsterdam University Press: Amsterdam; 37-54.

Kandel W, Massey D. 2002. The culture of Mexican migration: a theoretical and empirical analysis. Social Forces 80(3): 981-1004.

Krantz DL. 1998. Taming chance: social science and everyday narratives. Psychological Inquiry 9(2): 87-94.

Manis JG, Meltzer BN. 1994. Chance in human affairs. Sociological Theory 12(1): 45-56.
Mayhew BH, McPherson M, Rotolo T, Smith-Lovin L. 1995. Sex and ethnic heterogeneity in face-to-face groups in public places: an ecological perspective on social interaction. Social Forces 74: 5-52.

McPherson M, Smith-Lovin L, Cook JM. 2001. Birds of a feather: homophily in social networks. Annual Review of Sociology 27: 415-444.

Nieswand B. 2010. Enacted destiny. West African charismatic Christians in Berlin and the immanence of God. Journal of Religion in Africa 40: 33-59.

Papadopoulou A. 2004. Smuggling into Europe: transit migrants in Greece. Journal of Refugee Studies 17(2): 167-184.

Pascual-de-Sans A. 2004. Sense of place and migration histories idiotopy and idiotope. Area 36: 348-357.

Portes A, Sensenbrenner J. 1993. Embeddedness and immigration: notes on the social determinants of economic action. American Journal of Sociology 98(6): 1320-1350.

Ray A, van Oudenaarden A. 2008. Nature, nurture, or chance: stochastic gene expression and its consequences. Cell 135(2): 216-226.

Schapendonk J. 2011. Turbulent Trajectories. Sub-Saharan African Migrants Heading NorthPhD. Thesis. Nijmegen School of Management. Radboud University: Nijmegen.

Schapendonk J. 2012. Turbulent trajectories: African migrants on their way to the European Union. Societies 2: 27-41.

Shanahan MJ, Porfeli EJ. 2006. Chance events in the life course. Advances in Life Course Research 11(6): 97-119.

Suter B. 2012. Social networks in transit: experiences of Nigerian migrants in Istanbul. Journal of Immigrant $\mathcal{E}$ Refugee Studies 10: 204-222.

Venkatesh S. 2009. Gang Leader for a Day. A Rogue Sociologist Crosses the Line. Penguin: London.

Williams AM, Baláž V. 2012. Migration, risk, and uncertainty: theoretical perspectives. Population, Space and Place 18: 167-180.

Wiseman R. 2003. The luck factor. The Magazine for Science and Reason 27(3): 1-5.

Yükseker D, Brewer KD. 2011. Astray and stranded at the gates of the European Union: African transit migrants in İstanbul. New Perspectives on Turkey 44: 129-159. 